\title{
Pengembangan sistem komposting melalui Bank Sampah di Desa Petani, Kecamatan Bathin Solapan
}

\author{
Suwondo*, Darmadi, \& Andri Hendrizal \\ Fakultas Keguruan dan Ilmu Pendidikan, Universitas Riau \\ *Wondo_su@yahoo.co.id
}

\begin{abstract}
Abstrak. Pengabdian kepada masyarakat adalah usaha untuk menyebarluaskan ilmu pengetahuan, teknologi, dan seni kepada masyarakat. Kegiatan tersebut harus mampu memberikan suatu nilai tambah bagi masyarakat, baik dalam kegiatan ekonomi, kebijakan, dan perubahan perilaku (sosial). Tujuan dalam kegiatan pengabdian masyarakat di Desa Petani, Kecamatan Bathin Solapan adalah masyarakat dapat berperan aktif dalam mengoptimalkan bank sampah yang ada guna membentuk suatu sistem pengelolaan sampah yang baik, meningkatkan budaya bersih dan ekonomi masyarakat. Masyarakat dapat memanfaatkan sampah organik yang dikumpulkan dari setiap rumah warga yang diserahkan langsung ke bank sampah untuk proses komposting. Tingkat ketercapaian sasaran program yang dilakukan di desa petani kecamatan bathin solapan sangat bagus dan tepat sasaran, hal ini didasarkan oleh antusiasnya masyarakat beserta ketua batin (adat) dalam melihat proses pelatihan pengolahan sampah organik menjadi kompos dengan menggunakan drum komposter yang telah disiapkan oleh tim pengabdian universitas riau dan mahasiswa universitas riau. Drum komposter merupakan metode pengolahan kompos yang efektif untuk masyarakat di Desa Petani Kecamatan Bathin Solapan dengan skala rumah tangga. Analisis pengembangan sistem composting melalui bank sampah di desa petani, kecamatan bathin solapan bertujuan agar masyarakat dapat berperan aktif dalam mengoptimalkan bank sampah yang ada guna membentuk suatu sistem pengelolaan sampah yang baik.
\end{abstract}

Kata kunci: pengabdian, komposting, budaya, bersih

Abstract. Community service is an effort to disseminate science, technology and art to society. These activities must be able to provide an added value for the community, both in economic activities, policies, and changes in (social) behavior. The goal of community service activities in Farmers Village, Bathin Solapan District is that the community can play an active role in optimizing existing waste banks in order to form a good waste management system, improving the clean culture and economy of the community. The community can take advantage of the organic waste collected from each resident's house which is submitted directly to the waste bank for the composting process. The level of achievement of the program targets carried out in the farmer village of the Inner Solapan sub-district is very good and right on target, this is based on the enthusiasm of the community and the spiritual (adat) chairman in seeing the training process for processing organic waste into compost using a composter drum that has been prepared by the service team riau university and riau university students. Drum composter is an effective compost processing method for the community in Desa Petani, Kecamatan Bathin Solapan, on a household scale. Analysis of the development of a composting system through a waste bank in a farmer village, in the sub-district of Inner Solapan aims for the community to play an active role in optimizing existing waste banks to form a good waste management system.

Keywords: devotion, composting, culture, clean

To cite this article: Suwondo., Darmadi., \& A. Hendrizal. 2020. Pengembangan sistem komposting melalui Bank Sampah di Desa Petani, Kecamatan Bathin Solapan. Unri Conference Series: Commnity Engagement 2: $445-453$. https://doi.org/10.31258/unricsce.2.445-453

(C) 2020 Authors

Peer-review under responsibility of the organizing committee of Seminar Nasional Pemberdayaan Masyarakat 2020 


\section{PENDAHULUAN}

Kecamatan Bathin Solapan merupakan salah satu Kecamatan di yang terletak di Kabupaten Bengkalis, dimana sebagian besar penduduk memiliki profesi sebagai buruh, wiraswasta, dan petani. Padatnya jumlah penduduk di di Kecamatan Bathin Solapan menyebabkan banyaknya sampah yang dihasilkan. Menurut data Unit Pelaksana Teknis (UPT) Pengelolaan Sampah tahun 2017 volume sampah di kecamatan Bathin Solapan meningkat setiap bulannya. Total volume sampah pada 2017 mencapai $23.175 \mathrm{~m} 2$, sementara fasilitas penampungan sementara sampah (TPS) masih sangat minim. Tercatat Hanya ada 7 titik TPS dan berada di pusat-pusat kecamatan. Dalam Peraturan Daerah Kabupaten Bengkalis No 2 Tahun 2015 Pasal 8 ayat 2 menjelaskan bahwa pemerintah daerah bertanggungjawab melaksanakan penyelenggaraan pengelolaan sampah di daerah, dalam pasal 3 juga dijelaskan bahwa tujuan pengelolaan sampah dalam Peraturan Daerah ini adalah untuk mewujudkan lingkungan yang sehat dan bersih, meningkatkan kesehatan masyarakat, kualitas lingkungan dan menjadikan sampah sebagai sumber daya yang bermanfaat secara ekonomi bagi daerah.Oleh karena itu, Pemahaman masyarakat akan pentingnya pemanfaatan sampah perlu ditingkatkan.

Penyelesaian permasalahan sampah harus diselesaikan oleh seluruh lapisan masyarakat baik dari pemerintah daerah, petugas kebersihan, dan masyarakat (Amasuomo and Baird 2016) Salah satunya dengan penerapan prinsip 3R (reduce, reuse, recycle) dalam wujud Bank Sampah. Sistem ini berfungsi mengelola sampah dengan menampung, memilah dan mendistribusikan sampah ke fasilitas pengolahan sampah lain, sehingga sampah di tempat pembuangan akhir bisa berkurang dan bahkan menambah nilai guna barang yang sebelumnya dianggap tidak berguna. Dalam Peraturan Daerah Kabupaten Bengkalis No 2 Tahun 2015 Pasal 1 ayat 51 bahwa Bank sampah adalah tempat pemilahan dan pengumpulan sampah yang dapat didaur ulang dan/atau diguna ulang sehingga memiliki nilai ekonomi. Bank sampah yang ada di Kecamatan Bathin Solapan hanya ada satu dan resmi diakui oleh Pemerintah Kabupaten Bengkalis yaitu Bank Sampah Pematang Pudu Bersih (BS PPB) yang berada di Jl. Bakti Kopelapip RT.002 RW.016 Kel. Pematang Pudu Kecamatan Bathin Solapan Kabupaten Bengkalis. Bank sampah ini berguna untuk mengelola dan mendaur ulang sampah rumah tangga atau non-organik, namun bank sampah yang ada tidak menampung sampah organik.

Menurut data Direktorat Jenderal Cipta Karya tahun 2017, komposisi sampah di Indonesia didominasi oleh sampah organik, yakni mencapai $60 \%$ dari jumlah sampah keseluruhan. Apabila sampah organik tidak dikelola dengan baik atau hanya berakhir di TPA dapat terjadi penguraian secara tidak alami dan menghasilkan metana, gas rumah kaca yang 25 kali lebih berbahaya daripada karbon dioksida. Hal ini tentu memberikan kontribusi terhadap pemanasan global dan perubahan iklim. Karena itu pengumpulan dan pengelolaan sampah organik melalui bank sampah sangat diperlukan. Penyelesaian permasalahan sampah harus diselesaikan oleh seluruh lapisan masyarakat baik dari pemerintah daerah, petugas kebersihan, dan masyarakat. Undang-undang No 18 tahun 2008 mengamanatkan pengelolaan sampah dengan prinsip 3R (reduce, reuse, recycle)

Setelah dikumpulkan dari bank sampah, sampah organik kemudian dapat dikelola menjadi pupuk organik/kompos melalui proses komposting (Mulasari, Husodo, and Muhadjir 2016). Selain dapat mengatasi permasalahan sampah, proses komposting ini juga menghasilkan pupuk organik yang bermanfaat untuk mengurangi ketergantungan petani pada pupuk kimia.

Tujuan dalam kegiatan pengabdian masyarakat di Desa Petani, Kecamatan Bathin Solapan adalah : meningkatkan pengelolaan sampah organik agar tidak mengganggu lingkungan masyarakat desa petani kecamatan bathin solapan, setiap masyarakat desa petani kecamatan bathin solapan dapat menghasilkan pupuk organik skala rumah tangga dengan menggunakan drum komposter, meningkatkan pendapatan ekonomi masyarakat desa petani kecamatan bathin solapan dalam menghasilkan pupuk organik/kompos yang memiliki daya jual.

\section{METODE PENERAPAN}

Program pengelolaan sampah dilakukan di Desa Petani, Kecamatan Bathin Solapan, Kabupaten Bengkalis. Sasaran kegiatan adalah masyarakat lokal yang merupakan perwakilan desa di Kec. Bathin Solapan. Pemilihan desa disesuaikan dengan penempatan mahasiswa Skripsi UNRI. Lingkup kegiatan yang akan dilakukan adalah:

1. Menyiapkan petunjuk teknis pembuatan pupuk kompos dari limbah domestik sekitar

2. Menyediakan sarana pengelolaan sampah sederhana untuk pelaksanaan komposting

3. Melakukan sosialisasi, pelatihan dan pendampingan terhadap masyarakat lokal dalam pengelolaan sampah Target luaran yang dihasilkan adalah:

1. Tersedianya petunjuk teknis pembuatan kompos

2. Masyarakat dapat melaksanakan program komposting secara mandiri 
Tahapan kegiatan yang akan dilakukan untuk pengabdian kepada masyarakat terdiri dari tahap persiapan, pelaksanaan, dan pelaporan. Secara rinci sebagai berikut.

\section{Tahap Perencanaan}

Tahap persiapan merupakan tahap perlengkapan administrasi dan penyamaan persepsi terkait lingkup dan target pekerjaan. Tahap persiapan selengkapnya adalah sebagai berikut:

1. Penyiapan administrasi dan kepastian kegiatan pengabdian masyarakat

2. Penyusunan rencana detail kegiatan dan waktu pelaksanaan kegiatan. Rencana detail kegiatan ini akan menjadi acuan kegiatan selama kegiatan pengabdian dilaksanakan.

3. Persiapan tim pelaksana sesuai dengan bidang keahlian yang diperlukan. Kegiatan juga melibatkan mahasiswa Akhir (Skripsi) Universitas Riau sebanyak 2 Orang yang ditempatkan di Kecamatan Bathin Solapan.

\section{Tahap Pelaksanaan}

Tahap pelaksanaan merupakan kegiatan pelaksanaan program. Hal-hal yang dilakukan adalah sebagai berikut:

1. Sosialisasi Kegiatan

Sosialisasi dilakukan untuk memberikan pengenalan tentang sistem komposting kepada masyarakat Kecamatan Bathin Solapan. Informasi yang disampaikan tentang pengertian, alur pengelolaan sampah, proses komposting, serta manfaat komposting untuk pertanian masyarakat.

2. Pembentukan tim pengelolaan sampah perwakilan kelurahan

Pembentukan tim pengelolaan sampah di kelurahan dilakukan melalui diskusi/rembuk warga dengan pihak pemerintah kelurahan.

3. Pemilihan dan persiapan lokasi

Pemilihan lokasi pusat pengelolaan sampah dilakukan untuk mendukung pusat pengolahan limbah dengan metode komposting. Secara umum komponen yang perlu dipertimbangkan dan dipersiapkan adalah sebagai berikut:

Tabel 1. Komponen yang dipertimbangkan dan dipersiapkan

\begin{tabular}{lll} 
No & \multicolumn{1}{c}{ Komponen } & \multicolumn{1}{c}{ Keterangan } \\
\hline 1 & Status kepemilikan lahan & $\begin{array}{l}\text { Diupayakan milik Kelurahan yang dapat digunakan } \\
\text { sebagai Pusat Pengelolaan Sampah } \\
\text { minimal 3 buah }\end{array}$ \\
2 & Jumlah Pengolahan Kompos & Kondisi baik dan tidak terlalu jauh dari masyarakat \\
3 & Aksesibilitas & $\begin{array}{l}\text { Diupayakan berada dan/atau sekitar lahan TPS/TPA yang } \\
\text { sudah ada }\end{array}$ \\
4 & Lokasi & Ketersediaan masyarakat iuran pengelolaan sampah \\
5 & Sumber dana & $\begin{array}{l}\text { Pembentukan kelembagaan dan peraturan pengelolaan } \\
\text { sampah secara lokal }\end{array}$ \\
6 & Kelembagaan & $\begin{array}{l}\text { Identifikasi dan analisis skala layanan pengelolaan } \\
\text { sampah yang telah dan akan dilakukan }\end{array}$ \\
7 & Kapasitas pengelolaan sampah &
\end{tabular}

4. Persiapan dan penyediaan sarana prasarana pendukung

a. Survei Timbulan Sampah, Komposisi dan Karakteristik Sampah

Berdasarkan SNI 19-2454-2002 tentang Tata cara Pengelolaan Sampah Perkotaan, timbulan sampah adalah banyaknya sampah yang timbul dari masyarakat dalam satuan volume maupun berat per kapita perhari, atau per luas bangunan, atau perpanjang jalan. Adapun tujuan dari penghitungan timbulan dan komposisi sampah adalah untuk merencanakan proses daur ulang/pengurangan sampah. Rata-rata 
timbulan sampah biasanya akan bervariasi dari hari ke hari, antara satu daerah dengan daerah lainnya, antara satu negara dengan negara lain. Penghitungan Potensi Timbulan Sampah di Kawasan Permukiman:

1. Berdasarkan standar yang berlaku tentang spesifikasi timbulan sampah;

2. Data-data hasil kajian dan komparasi terhadap TPS dan TPA yang sudah operasional;

3. Hasil kajian lapangan;

4. Penghitungan timbulan sampah berdasarkan teknik pengambilan sampah berdasarkan standar yang berlaku; dan/atau

5. Penghitungan komposisi sampah merencanakan proses daur ulang/pengurangan sampah.

b. Penyediaan sarana dan prasarana pendukung

Persiapan sarana dan prasarana pendukung berupa penyediaan alat dan bahan berupa penyiapan sebuah pusat pengumpulan dan pengolahan sampah yang dilengkapi dengan fasilitas sebagai berikut:

Tabel 2. Komponen yang dipertimbangkan dan dipersiapkan

\begin{tabular}{llc} 
No & Peralatan & Jumlah \\
\hline 1 & Bak Penampungan Sampah & 1 Buah \\
2 & Bak pemisah jenis sampah (Organik dan anorganik) & 4 Buah \\
3 & Gudang peralatan & 1 Buah \\
4 & Peralatan komposting & 1 Paket \\
\hline
\end{tabular}

5. Penyusunan petunjuk teknis pelaksanaan komposting

Penyusunan petunjuk teknis disusun untuk menjadi acuan pelaksanaan komposting agar bersifat teknis. Panduan yang disusun melingkupi:

a. Teknik penampungan dan pemilahan sampah;

b. Sistem penimbangan

c. Pencatatan sampah

d. Pengangkutan sampah

e. Pembuatan kompos

f. Perawatan dan pemeliharaan sarana

6. Melakukan bimbingan teknis dan pendampingan.

Bimbingan teknis dilakukan dengan terhadap masyarakat yang telah dipilih dari hasil rembuk warga. Bimbingan teknis dilakukan selama 1 hari dengan metode action-simulation oleh dosen dan mahasiswa Skripsi Unri. Setelah dilakukan Bimbingan teknis selanjutnya masyarakat diminta melaksanakan secara mandiri dengan tetap dilakukan pendampingan selama 2 bulan. Pendampingan dilakukan untuk memastikan bahwa masyarakat telah dapat dilakukan secara mandiri.

7. Monitoring dan Evaluasi

Monitoring dan evaluasi dilakukan secara berkala setiap 1 kali setiap bulan. Monitoring dan evaluasi bertujuan untuk memastikan bahwa sistem pengelolaan sampah masih berjalan dan sesuai dengan panduan teknis yang telah dibuat.Monev dilakukan oleh dosen dan perwakilan mahasiswa skripsi unri.

\section{HASIL DAN KETERCAPAIAN SASARAN}

Kegiatan pengabdian yang dilakukan di desa petani kecamatan bathin solapan telah menghasilkan suatu ketercapaian berupa: alat komposter dengan menggunakan metode drum komposter skala rumah tangga dan juga Poster tata cara pengolahan kompos dengan menggunakan metode drum komposter skala rumah tangga, adapun kesulitan yang dihadapi oleh mitra adalah masih kurangnya antusias masyarakat dalam melakukan pengolahan sampah organik menjadi kompos.

Proses pengomposan adalah proses dekomposisi yang dilakukan oleh mikroorganisme terhadap bahan organik biodegradable (Singh, et al. 2014). Perubahan alur pemikiran kadang harus mengalahkan gengsi dan strata kedudukan di masyarakat. Padahal fungsi sampah tidak hanya untuk dipanen dan menambah pendapatan tetapi juga dapat membuat lingkungan yang lebih sehat sehingga masalah kesehatan penduduk bisa lebih terjaga. Di samping itu pencemaran lingkungan dapat dikurangi bahkan dihilangkan sehingga tidak hanya 
manusianya yang sehat tetapi semua anggota ekosistem ikut terjaga, kesejahteraan masyarakat akan meningkat dan juga meningkatkan pendapatan. Kegiatan ini akan timbul wirausaha wirausaha baru diantaranya pengepul sampah plastik/organik dan juga produsen pupuk organik, sehingga lingkungan menjadi bersih dan menghasilkan lingkungan yang subur dengan ini semua potensi di desa dapat diolah menjadi barang yang menghasilkan dan mengurangi pengeluaran di masa pandemi covid-19 ini.

\section{Gambaran umum masyarakat sasaran}

Desa Petani merupakan salah satu diantara 13 Desa dan Kelurahan dalam Kecamatan Bathin Solapan, Kabupaten Bengkalis, Provinsi Riau. Desa Petani berbatasan langsung dengan Desa Sebangar di sebelah utara, Kelurahan Pematang Pudu di sebelah timur, dan di sebelah barat berbatasan dengan kabupaten Rokan Hulu. Desa Petani Kecamatan Bathin Solapan memiliki luas wilayah seluas 99.36 e dengan jarak lurus menuju pusat pemerintahan sejauh $12 \mathrm{~km}$. Kondisi geografis pada desa petani berupa daratan. Berdasarkan jumlah penduduk di desa petani berjumlah 6621 jiwa dengan pembagian laki-laki 3473 dan perempuan sebanyak 3148 sedangkan jumlah keluarga sebesar 1879 kk. Masyarakat penduduk yang tinggal di Desa Petani umumnya mayoritas suku Melayu Sakai. Selain itu juga masih terdapat beberapa suku bangsa lainnya yang dulunya juga adalah sebagai pendatang di Desa Petani ini. Pendatang itu adalah bersuku Batak Toba, Jawa yang dimana mereka membeli lahan persawitan di Desa Petani tersebut maka mereka tinggal menetap.

\section{Potensi pengembangan (pemberdayaan) masyarakat}

Sebagai desa yang memiliki jumlah penduduk yang selalu meningkat setiap tahunnya, desa petani memiliki potensi untuk dilakukan pengolahan sampah organik menjadi kompos, hal ini berdasarkan perilaku masyarakat yang selalu membuang sampah organik ke belakang rumah tanpa dilakukan pengolahan. masyarakat desa petani akan dituntun untuk dapat melakukan pengolahan sampah organik menjadi kompos dalam skala rumah tangga agar menjadi penunjang proses pertanian yang selalu dilakukan oleh masyarakat desa petani di belakang rumah mereka dan juga dapat menjadi penggerak perekonomian masyarakat setempat menjadi lebih mandiri. Adapun kunjungan awal terhadap lingkungan masyarakat desa petani kecamatan Bathin Solapan dapat dilihat pada gambar dibawah berikut ini.

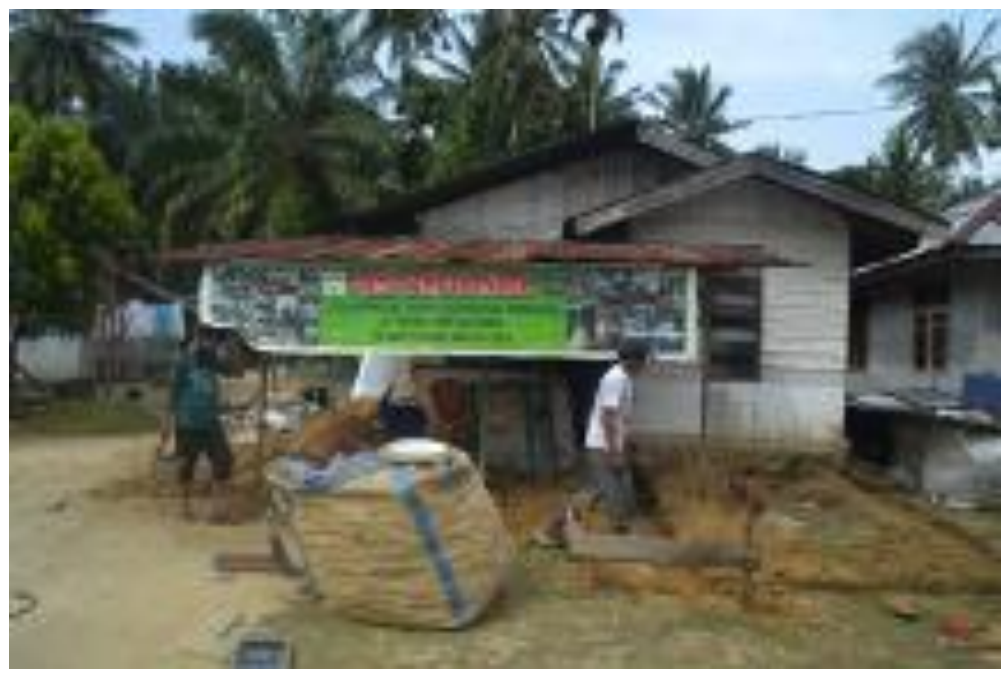

Gambar 1. Kondisi Bank Sampah Indah Bathin Solapan 


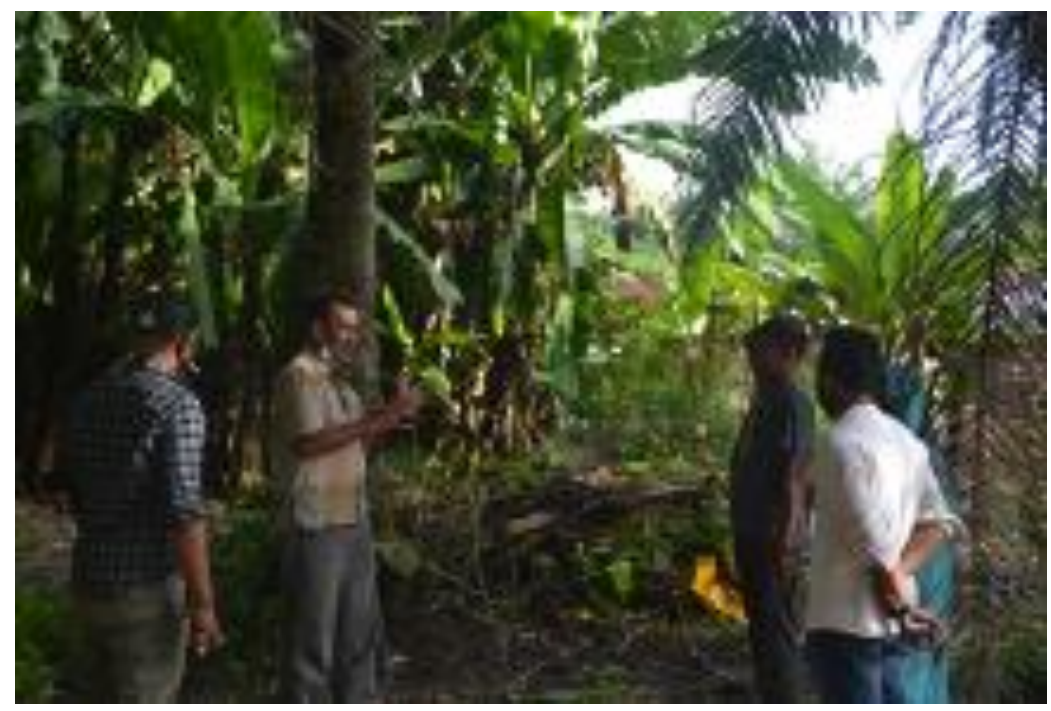

Gambar 2. Pemberian Arahan Pengolahan Sampah Menjadi Kompos

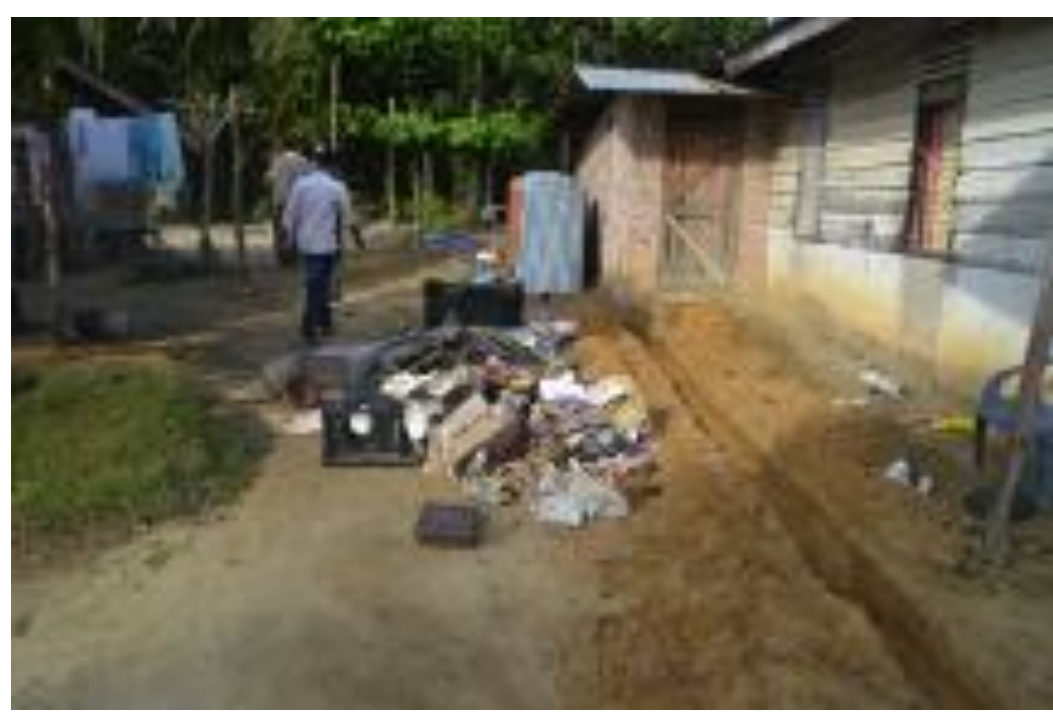

Gambar 3. Kondisi di sekitar rumah penduduk

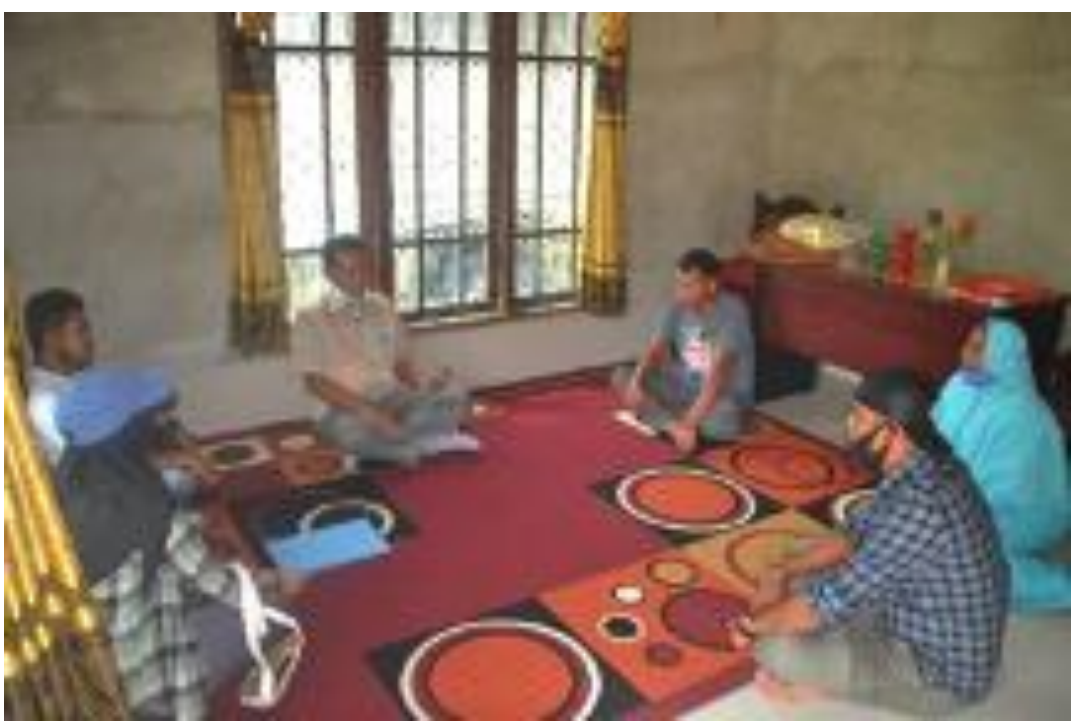

Gambar 4. Melakukan Sosialisasi terhadap ketua adat yang berada di desa petani 


\section{Solusi pengembangan (pemberdayaan) masyarakat}

Adapun solusi pengembangan masyarakat yang berada di Desa Petani Kecamatan Bathin Solapan yaitu dengan melakukan pengolahan sampah organik menjadi kompos dengan menggunakan metode Drum Komposter, hal ini berdasarkan pengembangan metode pengolahan kompos yang berada di universitas riau, metode pengolahan kompos dengan menggunakan Drum Komposter ini dapat diimplementasikan kepada setiap masyarakat yang berada di desa Bathin Solapan dikarenakan Drum Komposter memiliki Desain yang Efisien dan Simple yang dapat digunakan oleh setiap orang, Kompos yang dihasilkan dari proses degradasi, baik pada pengomposan tradisional maupun pada pengomposan modern (pengomposan dipercepat) disebut sebagai kompos setengah matang yang belum stabil, dan tidak baik bila digunakan langsung pada tanaman (Badan Standardisasi Nasional 2004). Adapun desain metode pengolahan kompos Drum Komposter Dapat dilihat pada tabel dibawah berikut ini.

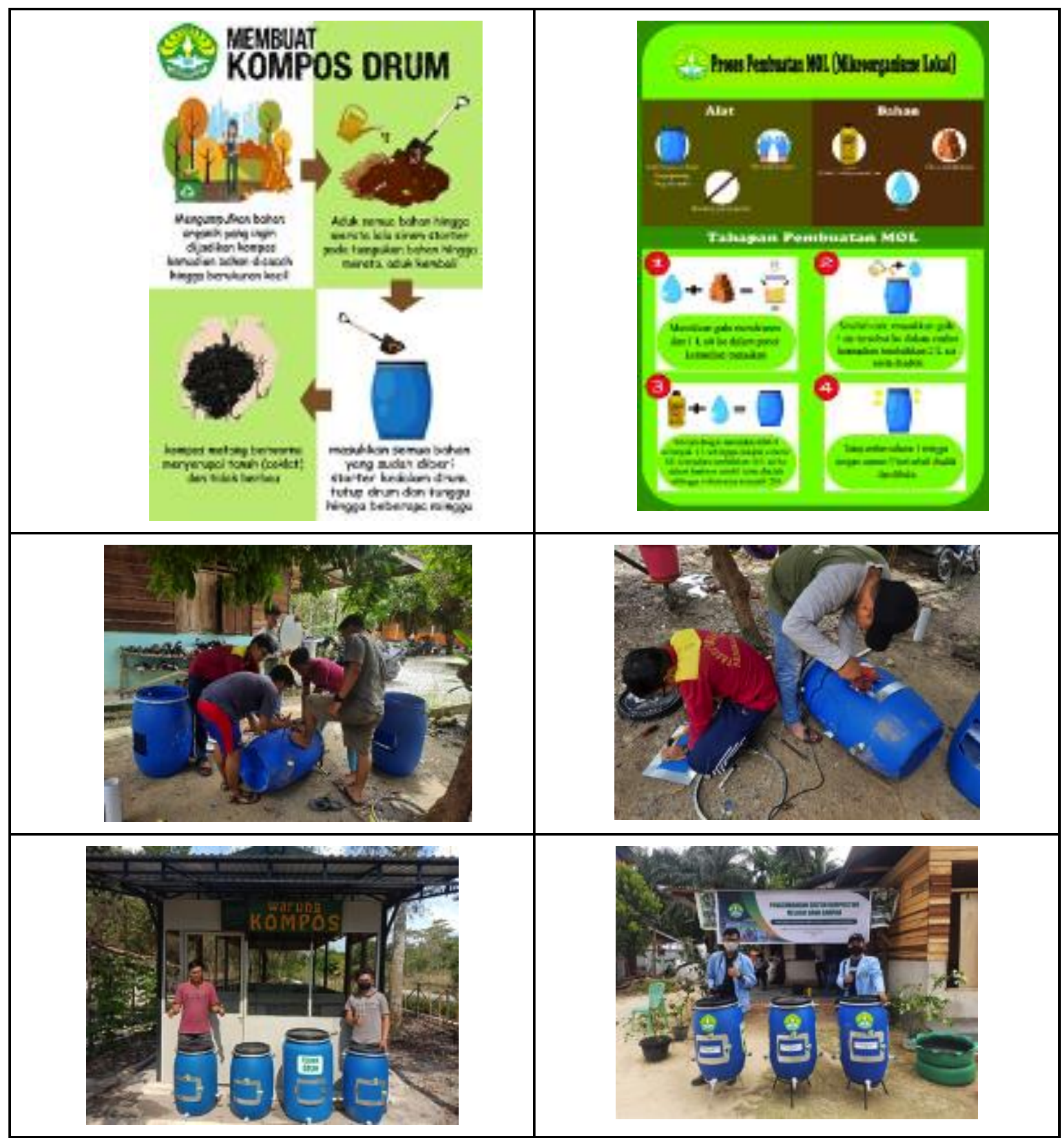

Gambar 5. Desain Dan Proses Pembuatan Drum Komposter Pengabdian Sakai Desa Petani 


\section{Tingkat ketercapaian sasaran program}

Adapun tingkat ketercapaian sasaran program yang dilakukan di desa petani kecamatan bathin solapan sangat bagus dan tepat sasaran, hal ini didasarkan oleh antusiasnya masyarakat beserta ketua bathin (adat) dalam melihat proses pelatihan pengolahan sampah organik menjadi kompos dengan menggunakan drum komposter yang telah disiapkan oleh tim pengabdian universitas riau dan mahasiswa universitas riau. Drum komposter merupakan metode pengolahan kompos yang efektif untuk masyarakat di Desa Petani, Kecamatan Bathin Solapan dengan skala rumah tangga.

Analisis pengembangan sistem composting melalui bank sampah di desa petani, kecamatan bathin solapan bertujuan agar masyarakat dapat berperan aktif dalam mengoptimalkan bank sampah yang ada guna membentuk suatu sistem pengelolaan sampah yang baik untuk meningkatkan budaya bersih dan ekonomi masyarakat sekitar yang serius mengelola proses pengomposan dengan menggunakan drum komposter. Sistem ini menampung, memilah, dan menyalurkan sampah bernilai ekonomi pada pasar sehingga masyarakat dapat memperoleh keuntungan ekonomi dari menabung sampah (Wulandari et al. 2014). Untuk itu masyarakat diharapkan dapat memanfaatkan sampah organik yang dikumpulkan di bank sampah untuk proses komposting. Adapun proses pengabdian yang telah dilakukan oleh tim pengabdian LPPM Universitas Riau dan mahasiswa serta masyarakat sekitar Desa Petani dan Kecamatan Bathin Solapan dan juga tidak lupa menerapkan sosial distancing untuk menjaga dari terpaparnya virus covid-19 dengan menggunakan masker dan menjaga jarak antar sesama dapat dilihat pada gambar dibawah berikut ini.

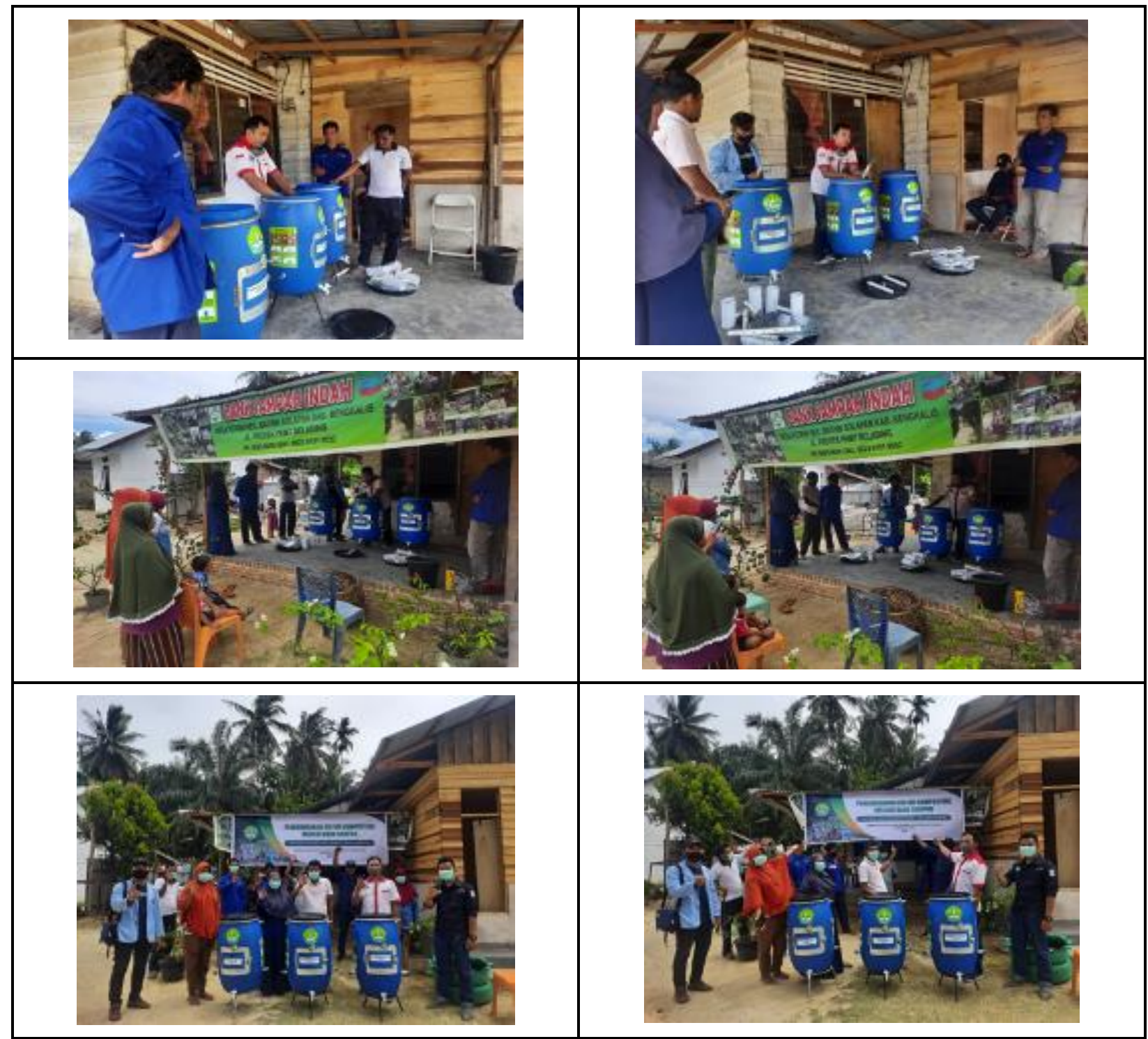

Gambar 6. Proses pengabdian yang dilakukan di desa petani kecamatan bathin solapan 


\section{KESIMPULAN}

Kegiatan pengabdian dan pelatihan pembuatan kompos menggunakan metode drum komposter di desa petani kecamatan bathin solapan telah meningkatkan wawasan masyarakat tentang pengolahan kompos skala rumah tangga dan menjadi pendapatan baru penduduk setempat, dengan kegiatan ini kondisi lingkungan desa menjadi bersih dan terhindar dari berbagai macam penyakit akibat membuang sampah sembarangan tanpa diolah dan juga meningkatkan kesadaran masyarakat akan kegunaan sampah, bahwa sampah bisa diolah dan akan meningkatkan pendapatan dan oleh karena itu tidak ada lagi masyarakat yang membuang sampah organik kebelakang rumah tanpa dilakukan pengolahan lebih lanjut. Sampah organik yang diolah akan akan berubah menjadi income/pendapatan masyarakat itu sendiri. Untuk keberlanjutan selanjutnya sebaiknya masyarakat setiap rumahnya memiliki komposter drum agar desa petani menjadi penghasil kompos skala rumah tangga yang berkembang.

\section{UCAPAN TERIMA KASIH}

Ucapan terimakasih diberikan kepada semua pihak yang telah membantu dalam pengabdian pengolahan kompos di desa petani kecamatan bathin solapan terutama masyarakat desa petani kecamatan bathin solapan yang telah mengikuti pelatihan pembuatan kompos sampai akhir acara dan kepada mahasiswa yang telah ikut membantu membuat desai dan tempat pengolahan drum komposter.

\section{DAFTAR PUSTAKA}

Amasuomo, Ebikapade, and Jim Baird. 2016. The Concept of Waste and Waste Management. Journal of Management and Sustainability, 6(4), 88.

Badan Standardisasi Nasional. 2004. Spesifikasi Kompos Dari Sampah Organik Domestik. Badan Standardisasi Nasional: 12 .

Direktorat Jenderal Cipta Karya. 2017. Petunjuk Teknis TPS 3R (Tempat Pengolahan Sampah 3R). 4-5. PUPRplpbm.pu.go.id > assets > file > Petunjuk Teknis TPS 3R 2017.

Mulasari, Surahma Asti, Adi Heru Husodo, and Noeng Muhadjir. 2016. Analisis Situasi Permasalahan Sampah Kota Yogyakarta Dan Kebijakan Penanggulangannya. Jurnal Kesehatan Masyarakat, 11(2), 259.

Singh, Jagdeep, Rafael Laurenti, Rajib Sinha, and Björn Frostell. 2014. Progress and Challenges to the Global Waste Management System. Waste Management and Research, 32(9), 800-812.

Wulandari, Damayanti, L., Asmura, J. 2014. Studi Karakteristik dan Potensi Pengolahan Sampah di Kampus Bina Widya Universitas Riau. JOM FTEKNIK, 1(2). 